\title{
Zirconium deficit as a tracer of urban sediment accumulation in Sustainable Urban Drainage Systems - Application to the calibration of a filtration model
}

Damien TEDOLDI ${ }^{1,2, *}$, Kelsey FLANAGAN ${ }^{1}$, Ghassan $\mathrm{CHEBBO}^{1,3}$, Philippe BRANCHU ${ }^{4}$, Daniel PIERLOT $^{2}$, and Marie-Christine GROMAIRE ${ }^{1}$

${ }^{1}$ LEESU, UMR MA 102, École des Ponts, AgroParisTech, UPEC, UPE, Champs-sur-Marne, 6-8 avenue Blaise Pascal, Cité Descartes, 77455 Marne-la-Vallée Cedex 2, France. damien.tedoldi@enpc.fr, kelsey.flanagan@enpc.fr, ghassan.chebbo@enpc.fr, marie-christine.gromaire@enpc.fr

${ }^{2}$ SEPIA, 53 rue de Turbigo, 75003 Paris, France. dp@sepia-uw.fr

${ }^{3}$ Faculty of Engineering III, Lebanese University, Hadath, Lebanon.

${ }^{4}$ CEREMA, 12 Rue Léon Teisserenc de Bort, 78190 Trappes, France. philippe.branchu@cerema.fr

*Corresponding author

\begin{abstract}
Among the processes governing contaminant retention in soil-based Sustainable Urban Drainage Systems (SUDS), quantifying the relative contribution of particle settling and filtration requires a tracer of runoffgenerated solids. Since zirconium $(\mathrm{Zr})$ is a widely used geochemical invariant in pedological approaches, with few anthropogenic sources, the present investigation aims to assess whether its use may be extended to sediment identification in SUDS. High-resolution horizontal and vertical soil sampling was carried out in 11 infiltration systems, as well as in road-deposited sediment. Following elemental analysis via X-ray fluorescence spectrometry, the spatial distribution of both $\mathrm{Zr}$ and urban-derived metals could be determined. $\mathrm{Zr}$ content in sediment was found to be fairly stable and significantly lower than in soil. In most devices, $\mathrm{Zr}$ and metals exhibited "mirror" trends, both horizontally and vertically, i.e. a deficit of $\mathrm{Zr}$ could be observed in the most contaminated area. This indicated a "dilution-like" mixture of soil and sediment, the fraction of which could be calculated and appraised spatially. The vertical profiles proved the occurrence of bed filtration over 5 to $15 \mathrm{~cm}$, and enabled the calibration of a simple filtration model. The uncertainties associated with the determined filter coefficient were found to be comparable to the other experimental methods - with the additional improvement that the present approach does not require water sampling.
\end{abstract}

\section{KEYWORDS}

Runoff infiltration, Soil, Urban environment, Urban sediment, X-ray fluorescence, Zirconium 


\section{INTRODUCTION}

Stormwater management close to the source, referred to variously as Low Impact Development (LID), Best Management Practices (BMPs), Water Sensitive Urban Design (WSUD), or Sustainable Urban Drainage Systems (SUDS), has gained popularity across the world (Fletcher et al., 2015), in order to mitigate the adverse effects of urban development and rising levels of impervious cover on the water cycle - namely, increased peak flows and annual volumes of runoff, faster hydrological response of the catchments, reduced infiltration and groundwater recharge (Fletcher et al., 2013; Miller et al., 2014), along with several qualitative impacts on the receiving water bodies (Hatt et al., 2004; McGrane, 2016). In addition to their widely recognized hydrologic and hydraulic benefits, these systems, and especially soil- or media-based devices, offer interesting perspectives towards the interception of diffuse pollutant fluxes in urban environments (Dierkes et al., 2015; Napier et al., 2009; Paus et al., 2013). On one hand, particle-bound contaminants in runoff are likely to be trapped with suspended solids via deposition and filtration, sometimes leading to the progressive formation of a sediment layer at the surface of infiltration systems (El-Mufleh $e t$ al., 2014; Erickson et al., 2013). On the other hand, dissolved species may undergo sorption onto various reactive constituents of the solid matrix (Sposito, 2008; Tedoldi et al., 2016). Since several contaminants such as trace metals are present in both dissolved and particulate forms in urban runoff, their accumulation in soil (or filter media) results from a combination of these physical and physico-chemical mechanisms.

Conventional experimental assessments of soil contamination in SUDS, which consist of collecting and analyzing soil samples after a known operation time, provide an overall and "time-integrated" vision of these retention processes (Kluge and Wessolek, 2012; Tedoldi et al., 2017a). However, they do not enable to differentiate between the relative contributions of settling/filtration and sorption, especially because runoff-generated solids - hereafter referred to as "sediment" - are not quantified in the solid phase.

As discussed by Clark and Pitt (2012), while infiltration practices are often designed according to empirical recommendations, and their treatment performance extrapolated from a limited number of field studies, a better understanding of the retention mechanisms taking place could valuably improve their choice, design and maintenance. Additionally, soil clogging by runoff sediment has often been reported as a major concern in infiltration systems, but it remains difficult to characterize and quantify the state of clogging in a given device, or even to anticipate the occurrence of hydraulic malfunction (Cannavo et al., 2018). Finally, if the long-term fate of contaminants in SUDS soil is to be appraised with a modelling approach, it seems necessary to consider the behavior of particle-bound species in addition to solute transport. Although several filtration models are available for this purpose (Logan, 2001), few authors attempted to do so (Li and Davis, 2008a), possibly because of the difficulty to calibrate such models with usual field data (Tedoldi et al., 2016). To this end, the vertical distribution of filtered particles - provided it may be accurately determined - may constitute useful calibration data. All these points highlight the interest of identifying a tracer of urban sediment accumulation in SUDS. 
The latter should (i) be conservative in a pedological acceptation, i.e. its content in soil should not be affected by runoff infiltration (neither via sorption nor via lixiviation), and (ii) display an anthropogenic signal different from the local background level in soils. The first point typically prevents the use of heavy metals such as copper or zinc, which are also present in the dissolved form in runoff (their average dissolved fractions reported by Huber et al. (2016) in road runoff were 38 and 31\%, respectively) and have a strong affinity for the soil constituents (Tedoldi et al., 2016).

Due to their very low mobility in soils under almost all environmental conditions, resistance to weathering, and very low availability to plants, elements such as titanium (Ti) and zirconium ( $\mathrm{Zr}$ ) are generally considered as geochemical invariants (Kabata-Pendias, 2011; Schulz, 1965; Shahid et al., 2013); hence, they are commonly used as references to calculate enrichment or depletion factors of other elements (Egli and Fitze, 2000; Stockmann et al., 2016). However, Ti has been quantified at relatively high levels (>1 g/kg) in urban road dust (Apeagyei et al., 2011), and has numerous anthropogenic sources including paint pigments, car manufacturing, and metallic alloys (Salminen, 2005). Conversely, the anthropogenic sources of $\mathrm{Zr}$ are quite limited - nuclear fallout and ceramic dust being the most frequently cited ones (Salminen, 2005; Shahid et al., 2013) -, as a result of which the contents in road dust were found to be much lower $(\sim 200 \mathrm{mg} / \mathrm{kg}$ ) (Apeagyei et al., 2011). It was observed that the presence of a dense urban area did not significantly impact $\mathrm{Zr}$ concentrations in both water and sediment from an urban stream (Mohiuddin et al., 2010). Furthermore, the lithogenic sources of $\mathrm{Zr}$ and its consequent abundance in most soils enable a systematic quantification with analytical methods such as X-ray fluorescence (Kabata-Pendias, 2011), thus providing the opportunity to extend the number of analyses and to achieve a finer description of its spatial variability.

Therefore, the objective of the present work is to assess the potential use of $\mathrm{Zr}$ as an unequivocal tracer of sediment accumulation in SUDS, and to illustrate a possible application with the calibration of a simple filtration model. The approach relies on high-resolution horizontal and vertical soil sampling from 11 infiltration systems, and subsequent analysis of both $\mathrm{Zr}$ and three typical urban- and traffic-derived trace metals $(\mathrm{Cu}, \mathrm{Pb}$, and $\mathrm{Zn}$ ). The latter, which are ubiquitous in stormwater runoff (Göbel et al., 2007; Huber et al., 2016), will be considered as a signature of runoff-induced contamination, and used as a comparison basis.

\section{MATERIALS \& METHODS}

\subsection{Description of the study sites}

Four small sized infiltration basins, five swales, and two grassed filter strips (Table 1), located in the Paris region (Figure 1), were selected for their contrasting hydraulic configurations, soil types, watersheds, and runoff contamination potentials (Tedoldi et al., 2017a). Inflow of water into the infiltration systems consists of either an inlet pipe (Dourdan, Greffiere, Alfortville, Vaucresson), or surface runoff directly flowing from 
the pavement, with a localized (Sausset2) or diffuse inflow (Sausset1, Chanteraines, Vitry, Compans1, Compans2, Compans3). In some devices, superficial outflow is possible in addition to infiltration: in the case of Dourdan, Chanteraines, and Vitry, this occurs when water ponding exceeds a given level, whereas in Compans1 and 2, water storage is supposedly achieved in a downstream longitudinal ditch; however, previous studies have shown that most water infiltrates in the roadside filter strips (Flanagan et al., 2017). Compans 3 is equipped with a $\mathrm{V}$ notch weir.

In Chanteraines, Vitry, Compans1 and 2, the surface soil displays a 5 to $15 \%$ slope perpendicular to the pavement; Alfortville and Compans 3 have a V-shaped transversal section; the rest of the facilities were constructed with flat bottoms and sharp embankments. Chanteraines, Vitry, and Compans 2 were excavated and backfilled with topsoil from another site during construction, as were Compans 1 and 3 with an engineered filter media (mixture of calcareous sand and loamy soil). The other systems were implemented upon the preexisting soil.

Table 1 - Main characteristics of the investigated infiltration facilities.

\begin{tabular}{|c|c|c|c|c|c|}
\hline Site name & Dourdan & Greffiere & Alfortville & Sausset1 & Sausset2 \\
\hline Type of device & $\begin{array}{l}\text { Infiltration- } \\
\text { retention basin }\end{array}$ & $\begin{array}{l}\text { Infiltration } \\
\text { basin }\end{array}$ & $\begin{array}{l}\text { Infiltration } \\
\text { basin }\end{array}$ & $\begin{array}{l}\text { Infiltration } \\
\text { basin }\end{array}$ & Small swale \\
\hline $\begin{array}{l}\text { Catchment } \\
\text { characteristics }\end{array}$ & $\begin{array}{l}\text { Two-lane } \\
\text { departmental } \\
\text { road }(4900 \\
\text { veh/day) + car } \\
\text { parking lot }\end{array}$ & $\begin{array}{l}\text { Residential } \\
\text { catchment: } \\
\text { houses with tile } \\
\text { roofs and } \\
\text { metallic } \\
\text { elements }\end{array}$ & $\begin{array}{l}\text { Industrial } \\
\text { activities }+ \\
\text { service roads }+ \\
\text { logistics area } \\
\text { (high truck } \\
\text { traffic) }\end{array}$ & $\begin{array}{l}\text { Car parking lot } \\
\text { (210 veh/day) }\end{array}$ & $\begin{array}{l}\text { Car parking lot } \\
\text { (210 veh/day) }\end{array}$ \\
\hline $\begin{array}{l}\text { Active area of } \\
\text { the catchment }\end{array}$ & $7000 \mathrm{~m}^{2}$ & $3000 \mathrm{~m}^{2}$ & $20000 \mathrm{~m}^{2}$ & $400 \mathrm{~m}^{2}$ & $160 \mathrm{~m}^{2}$ \\
\hline Device area $^{\ddagger}$ & $120 \mathrm{~m}^{2}$ & $65 \mathrm{~m}^{2}$ & $130 \mathrm{~m}^{2}$ & $68 \mathrm{~m}^{2}$ & $10 \mathrm{~m}^{2}$ \\
\hline Inflow of water & $\begin{array}{l}\text { Pipe } \\
(\emptyset 600 \mathrm{~mm}) \\
\text { followed by a } \\
\text { concrete apron }\end{array}$ & $\begin{array}{l}\text { Pipe } \\
\text { (Ø300 mm) }\end{array}$ & $\begin{array}{l}\text { Pipe } \\
\text { (Ø800 mm) }\end{array}$ & $\begin{array}{l}\text { Surface runoff, } \\
\text { large opening } \\
(90 \mathrm{~cm})\end{array}$ & $\begin{array}{l}\text { Surface runoff, } \\
\text { small opening } \\
(15 \mathrm{~cm})\end{array}$ \\
\hline Superficial outlet & $\begin{array}{l}\text { Elevated pipe } \\
(30 \mathrm{~cm} \text { above } \\
\text { the ground })\end{array}$ & None & None & None & None \\
\hline Operating time & $>20$ years & 15 years & 16 years & 14 years & 14 years \\
\hline $\begin{array}{l}\text { Soil texture } \\
(0-10 \mathrm{~cm})\end{array}$ & Sandy loam & $\begin{array}{l}\text { Sandy clay } \\
\text { loam }\end{array}$ & Clay loam & Silt loam & Silt loam \\
\hline Vegetation & $\begin{array}{l}\text { Spontaneous } \\
\text { vegetation }\end{array}$ & $\begin{array}{l}\text { Spontaneous } \\
\text { vegetation }\end{array}$ & $\begin{array}{l}\text { Spontaneous } \\
\text { vegetation }\end{array}$ & $\begin{array}{l}\text { Shrubs and } \\
\text { grass }\end{array}$ & $\begin{array}{l}\text { Herbaceous } \\
\text { plants }\end{array}$ \\
\hline
\end{tabular}


Table 1 (continued) - Main characteristics of the investigated infiltration facilities.

\begin{tabular}{|c|c|c|c|c|c|}
\hline Chanteraines & Vitry & Vaucresson & Compans1 & Compans2 & Compans3 \\
\hline Swale & Swale & Swale & Filter strip & Filter strip & Swale \\
\hline $\begin{array}{l}\text { Service road } \\
(<1500 \mathrm{veh} / \text { day }) \\
+ \text { small car } \\
\text { parking lot }\end{array}$ & $\begin{array}{l}\text { T-junction } \\
\text { within an } \\
\text { industrial } \\
\text { catchment (high } \\
\text { truck traffic) }\end{array}$ & $\begin{array}{l}\text { Two-lane } \\
\text { departmental } \\
\text { road ( } 4000 \\
\text { veh/day) }\end{array}$ & $\begin{array}{l}\text { Highway } \\
\text { (11000 veh/day } \\
\text { in each } \\
\text { direction) in the } \\
\text { vicinity of an } \\
\text { industrial area }\end{array}$ & $\begin{array}{l}\text { Highway } \\
\text { (11000 veh/day } \\
\text { in each } \\
\text { direction) in the } \\
\text { vicinity of an } \\
\text { industrial area }\end{array}$ & $\begin{array}{l}\text { Highway } \\
\text { (11000 veh/day } \\
\text { in each } \\
\text { direction) in the } \\
\text { vicinity of an } \\
\text { industrial area }\end{array}$ \\
\hline $470 \mathrm{~m}^{2}$ & $350 \mathrm{~m}^{2}$ & $400 \mathrm{~m}^{2}$ & $250 \mathrm{~m}^{2}$ & $250 \mathrm{~m}^{2}$ & $330 \mathrm{~m}^{2}$ \\
\hline $54 \mathrm{~m}^{2}$ & $19 \mathrm{~m}^{2}$ & $12 \mathrm{~m}^{2}$ & $33 \mathrm{~m}^{2}$ & $33 \mathrm{~m}^{2}$ & $23 \mathrm{~m}^{2}$ \\
\hline $\begin{array}{l}\text { Surface runoff, } \\
\text { diffuse inflow }\end{array}$ & $\begin{array}{l}\text { Surface runoff, } \\
\text { multiple lateral } \\
\text { openings }\end{array}$ & $\begin{array}{l}\text { Pipe } \\
(\varnothing 200 \mathrm{~mm})\end{array}$ & $\begin{array}{l}\text { Surface runoff, } \\
\text { diffuse inflow }\end{array}$ & $\begin{array}{l}\text { Surface runoff, } \\
\text { diffuse inflow }\end{array}$ & $\begin{array}{l}\text { Surface runoff, } \\
\text { diffuse inflow }\end{array}$ \\
\hline $\begin{array}{l}\text { Elevated pipe } \\
\text { ( } 25 \mathrm{~cm} \text { above the } \\
\text { ground) }\end{array}$ & $\begin{array}{l}\text { Elevated pipe } \\
(25 \mathrm{~cm} \text { above } \\
\text { the ground })\end{array}$ & None & $\begin{array}{l}\text { Longitudinal } \\
\text { ditch }\end{array}$ & $\begin{array}{l}\text { Longitudinal } \\
\text { ditch }\end{array}$ & V notch weir \\
\hline 10 years & 10 years & $>25$ years & 3 years & 3 years & 1 year \\
\hline Sandy loam & Loam $^{\star}$ & Clay loam & Sandy loam ${ }^{\star}$ & Silt loam ${ }^{\star}$ & Sandy loam ${ }^{\star}$ \\
\hline Grass & $\begin{array}{l}\text { Herbaceous } \\
\text { plants }\end{array}$ & $\begin{array}{l}\text { Spontaneous } \\
\text { vegetation }\end{array}$ & Grass & Grass & Grass \\
\hline
\end{tabular}

‡The given value corresponds to the area of the sampled section during the initial field investigations ( $c f$. Section 2.2).

${ }^{\star}$ Amended topsoil (different from the preexisting soil).
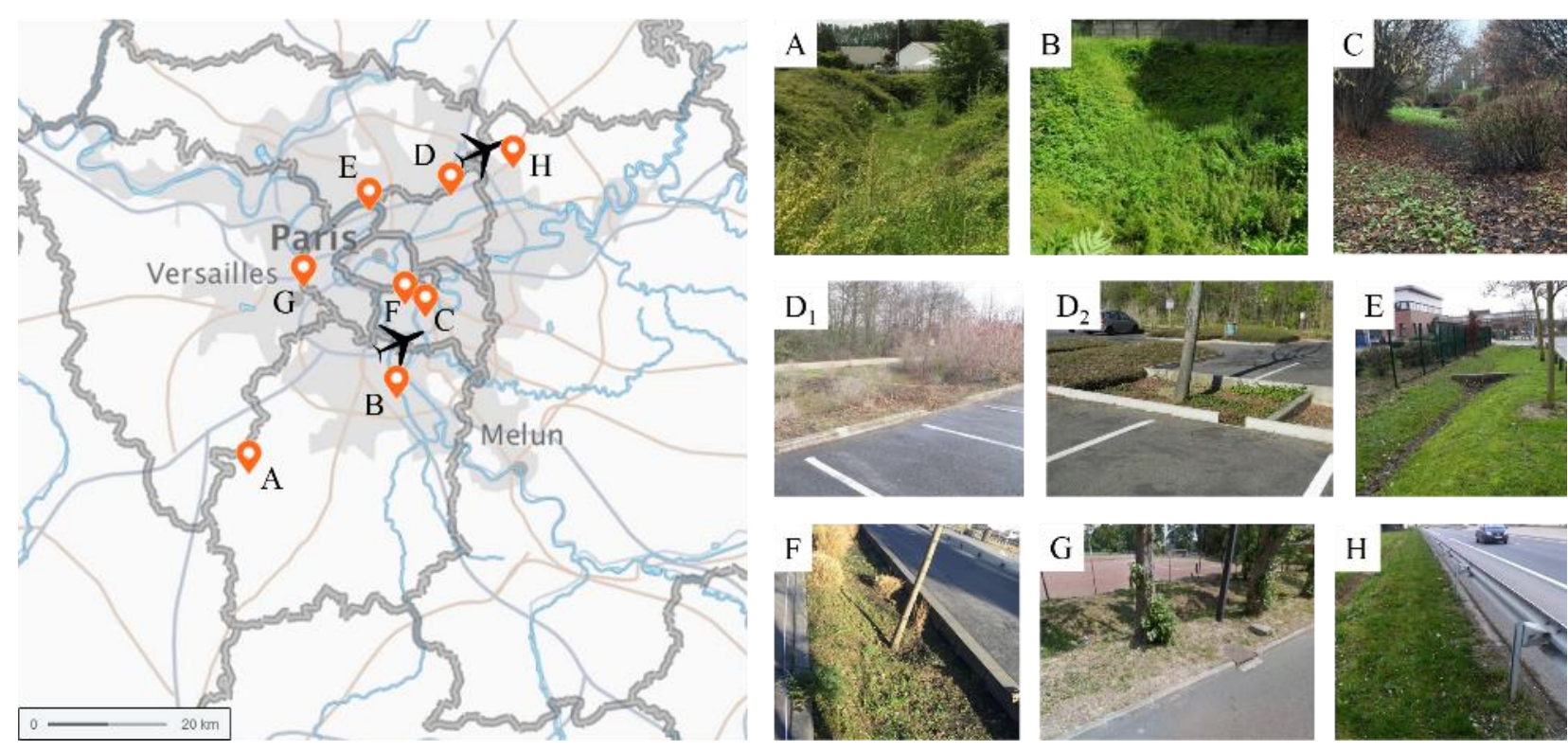

Figure 1 - Location and photographs of the study sites: A) Dourdan, B) Greffiere, C) Alfortville, D ${ }_{1}$ Sausset1, D 2 ) Sausset2, E) Chanteraines, F) Vitry, G) Vaucresson, H) Compans. 


\subsection{Sampling procedure}

The field investigations were undertaken in two phases between April 2015 and May 2016, so as to consecutively obtain the distribution of the chemical species of interest at the surface and along vertical profiles (Figure 2). Firstly, a systematic sampling of the surface horizon was carried out using a rectangular grid, with a mesh size adapted to each site so as to meet the strictest of these two criteria: $(i)$ collect $\geq 20$ samples per device, and (ii) collect $\geq 35$ samples $/ 100 \mathrm{~m}^{2}$. At each node, the vegetation was removed if present, then $\sim 50 \mathrm{~g}$ of surface soil (upper $2-3 \mathrm{~cm}$ ) was composited from $\geq 4$ subsamples surrounding the sampling location, using a stainless steel trowel which was subsequently cleaned and rinsed twice with ultrapure water. Altogether, nearly 550 soil samples were collected during this phase, all of which were conserved in individual high-density polyethylene bottles prior to analysis (Section 2.3).

This first characterization enabled the identification of the most and the least contaminated areas of each facility, defined as the domains where metal contents were respectively $(i)$ higher than the $9^{\text {th }}$ decile, and (ii) lower than the $1^{\text {st }}$ decile of the measurements in the site; the latter was considered as a "reference zone" (Figure 2). In each area, 4 core samples were collected with a stainless steel gouge auger, then the upper $30 \mathrm{~cm}$ were subdivided into 6 depth sections, with a higher resolution near the surface $(2.5$-cm-thick segments). For each depth, a composite sample ( $250 \mathrm{~g})$ was formed from the 4 corresponding subsamples. This step could not be completed in Vaucresson because of maintenance work undertaken by the municipality, which destructured the soil of the swale after the initial sampling campaign. In Compans 1 and 2, due to the presence of the road sub-base, the soil thickness in the most contaminated zone was insufficient to perform corings. A different methodology was thus applied, which consisted of collecting soil cores at several distances from the road $(30,70,120$, and $180 \mathrm{~cm})$, the thickness of which depended on the depth of the sub-base $(7-30 \mathrm{~cm})$; each core was then subdivided into 2 or 3 depth sections, and the samples were analyzed separately.

Whenever present, additional samples of raw sediment were collected on the nearby road pavement (Figure S1); such deposits could not be found in the immediate vicinity of Alfortville and Sausset.

\subsection{Sample preparation and analysis}

All samples (soil and sediment) were pre-treated according to the international standard on the preservation and pre-treatment of solid samples for the analysis of non-volatile species (ISO 11464, 2006), i.e. ovendried at $40^{\circ} \mathrm{C}$ for 7 days, ground with a pestle, then passed through a 2-mm nylon sieve. Elemental analysis was performed via X-ray fluorescence (XRF) spectrometry (Thermo Scientific, Portable Niton ${ }^{\mathrm{TM}}$ analyzer XL3t). 5 to 6 homogenized subsamples were poured as loose powder into polyethylene cells with a thin transparent film at the bottom, and analyzed independently. The elements of interest were copper, lead, zinc, and zirconium. The analysis time was set to $60 \mathrm{~s}$ per beam in a standard soil mode. The repeatability of the measurements was checked by calculating the relative standard deviation (RSD) of the 5-6 values for each element, which was always $<10 \%$, with an average of $4-5 \%$ for metals and $3 \%$ for $\mathrm{Zr}$; similar RSD were 
found for soil and sediment samples. Each sample was then assigned its average content of $\mathrm{Cu}, \mathrm{Pb}, \mathrm{Zn}$, and $\mathrm{Zr}$, calculated from the 5-6 measurements.

In the following developments, unless otherwise specified, soil concentrations will be given in milligrams per kilogram of dry matter (DM). The limits of quantification are sample-dependent, as they vary according to the signal received by the analyzer, but they were always $\leq 20,10$, and $30 \mathrm{mg} / \mathrm{kg} \mathrm{DM}$ for $\mathrm{Cu}, \mathrm{Pb}$, and $\mathrm{Zn}$, respectively, and $\leq 10 \mathrm{mg} / \mathrm{kg} \mathrm{DM}$ for $\mathrm{Zr}$.

Since $\mathrm{XRF}$ is a non-conventional practice for elemental analysis, a comparison with two reference approaches was carried out - i.e. ICP-based analyses on acid-digested samples (for $\mathrm{Cu}, \mathrm{Pb}, \mathrm{Zn}$ ) and NIST soil standards (for all elements) - in order to assess the reliability of the XRF-determined contents. The first approach, which has been published in a previous work (Tedoldi et al., 2017a), evidenced a satisfactory precision for $\mathrm{Cu}$ (mean deviation of $7 \%$ from the reference contents) and $\mathrm{Zn}(14 \%)$, and showed that $\mathrm{Pb}$ contents were consistently underestimated by $16 \mathrm{mg} / \mathrm{kg}$ (which in proportion is higher than for the other two metals - up to $80 \%$ - because $\mathrm{Pb}$ contamination is lower) when considering XRF measurements. The second approach displayed relative errors ranging from -12 to $5 \%$ for $\mathrm{Cu},-7$ to $16 \%$ for $\mathrm{Zn},-35$ to $-13 \%$ for $\mathrm{Pb}$, and 4 to $18 \%$ for $\mathrm{Zr}$ (negative values indicate an underestimation of the certified contents). Besides, it should be added that this analytical technique has been widely used for the quantification of $\mathrm{Zr}$ levels, e.g. for the construction of the Geochemical Atlas of Europe (Salminen, 2005), and the analysis of road dust (Apeagyei et al., 2011).

Additionally, a fraction $(\sim 10 \mathrm{~g})$ of each sample was calcined at $550^{\circ} \mathrm{C}$ for 6 hours, so as to determine its volatile matter content from mass difference.

\subsection{Data handling}

Surface contents were interpolated so as to generate cartographies of trace metals and zirconium, using a $10 \mathrm{~cm} \times 10 \mathrm{~cm}$ interpolation grid covering the whole sampled area of each device. In the subsequent results and discussion, the mention of the SUDS "surface soil" will refer to the layer sampled during this first step, i.e. the upper $2-3 \mathrm{~cm}$. The data acquired during the second phase were represented as vertical profiles, i.e. the evolution of the metal and $\mathrm{Zr}$ contents with increasing depth, in the two sampled zones (Figure 2). For Compans 1 and 2, instead of concentration profiles, the values were interpolated along the sampled transversal sections; the z-coordinate which was associated to each segment corresponded to its average depth, assuming that concentrations varied linearly within vertical samples - thus leading to a correspondence between the measured contents and the midpoint of the segments.

As some variables could not be considered as normally distributed, statistical correlations were assessed via Spearman's rank correlation coefficient $\rho$, and the associated non-parametric test of significance. $\rho_{X Y}$ corresponds to the Pearson's correlation coefficient between the rank values of the two variables $X$ and $Y$. 


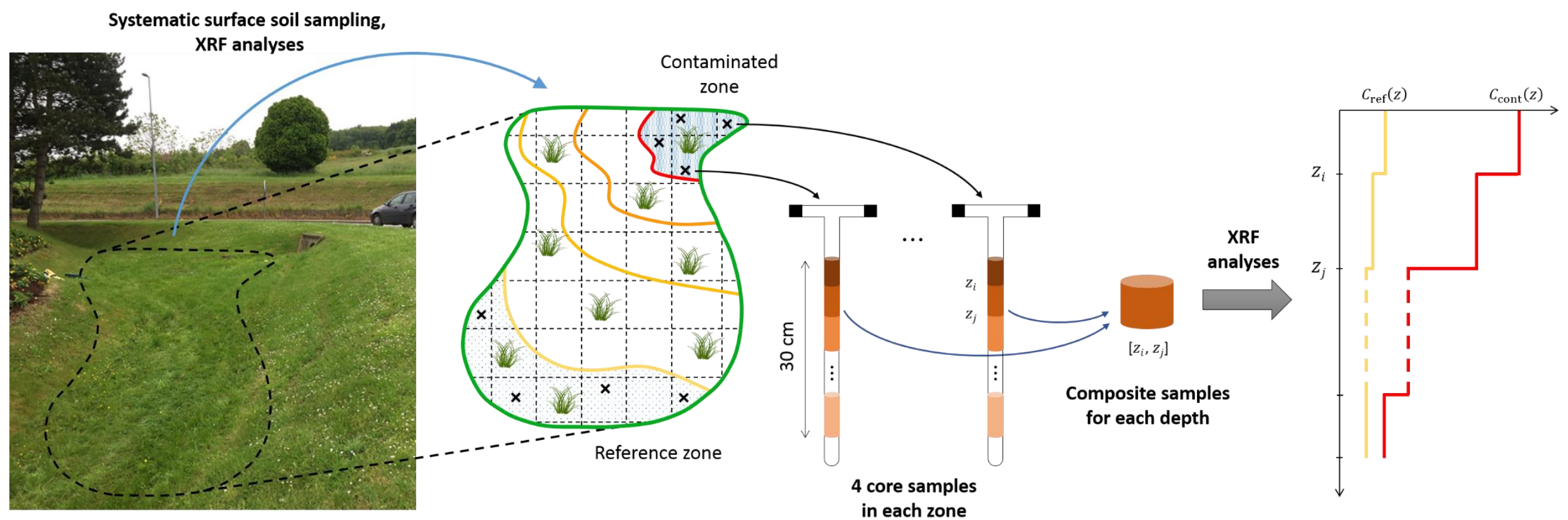

Figure 2 - Schematic representation of the two-step methodology for soil sampling and analysis. 


\section{RESULTS}

\subsection{Spatial distribution of metals and $\mathrm{Zr}$ in the surface soil}

Whatever the study site, $\mathrm{Cu}, \mathrm{Pb}$, and $\mathrm{Zn}$ exhibited similar distributions in the surface soil, which were characterized by a significant buildup near the inflow area, followed by a marked decrease in concentrations with increasing distance. Figures 3 and 4 present the results obtained for $\mathrm{Zn}$, while the distributions of the other two metals are presented as supplementary data (Figure S2). The difference in metal contents between the most and the least contaminated areas of each device is illustrated on Figure S3. Zn and Cu were strongly correlated with $\rho \geq 0.86$ (Table S1), which was statistically significant ( $p$-value $<10^{-10}$ ). This observation was also applicable for the $\mathrm{Zn}-\mathrm{Pb}$ correlations in most sites $(\rho \geq 0.84)$; lower - albeit significant correlations were found in Sausset1, Sausset2 and Chanteraines, where Pb contamination was inferior (because of limited loads from the watersheds) and the contents rapidly fell within the natural variability of the geochemical background. As a result, zinc could be considered representative of the metal's behavior in the topsoil of the devices, and will be focused on in the subsequent developments.

This spatial distribution, the origins and implications of which have been thoroughly discussed elsewhere (Tedoldi et al., 2017a), constituted a precise, "time-integrated" signature of both non-uniform infiltration fluxes and settling processes at the surface of each device. In particular, it provided evidence that the area affected by runoff-derived contamination was horizontally localized - with the exception of the Alfortville basin (Figure 3), whose atypical behavior was due to the presence of a clay horizon at $25 \mathrm{~cm}$ depth, thus preventing the fast infiltration of water near the inlet pipe: hence, the lowest part of the V-shaped basin (located at the coordinate $y=0$ ) was almost evenly polluted by trace metals.

Remarkably, Zr commonly showed "mirror" distributions with respect to metals: in other words, a deficit of this element could be observed in the most contaminated zone, with an opposite increasing trend toward the reference zone (Figures 3, 4, and S3). The marked - albeit reverse - similarity between $\mathrm{Zr}$ and metal distributions was generally characterized by negative correlations with various levels of significance (Table S1), leading to the following classification:

i. In Alfortville, Sausset1, Vitry, Compans1, and Compans2, the correlations were significant with $\rho \leq-0.78$ (excluding $\mathrm{Pb}$ in Sausset1 for the above-mentioned reasons).

ii. Dourdan, Sausset2, and Vaucresson displayed correlation coefficients between -0.79 and -0.53 $\left(p<10^{-3}\right)$.

iii. $\quad \mathrm{Zr}$ was heterogeneously distributed at the surface of the Greffiere, Chanteraines, and Compans3 devices - although in the second site a deficit could still be observed near the road pavement -, as a result of which no particular tendency could be noticed in relation to metals. 

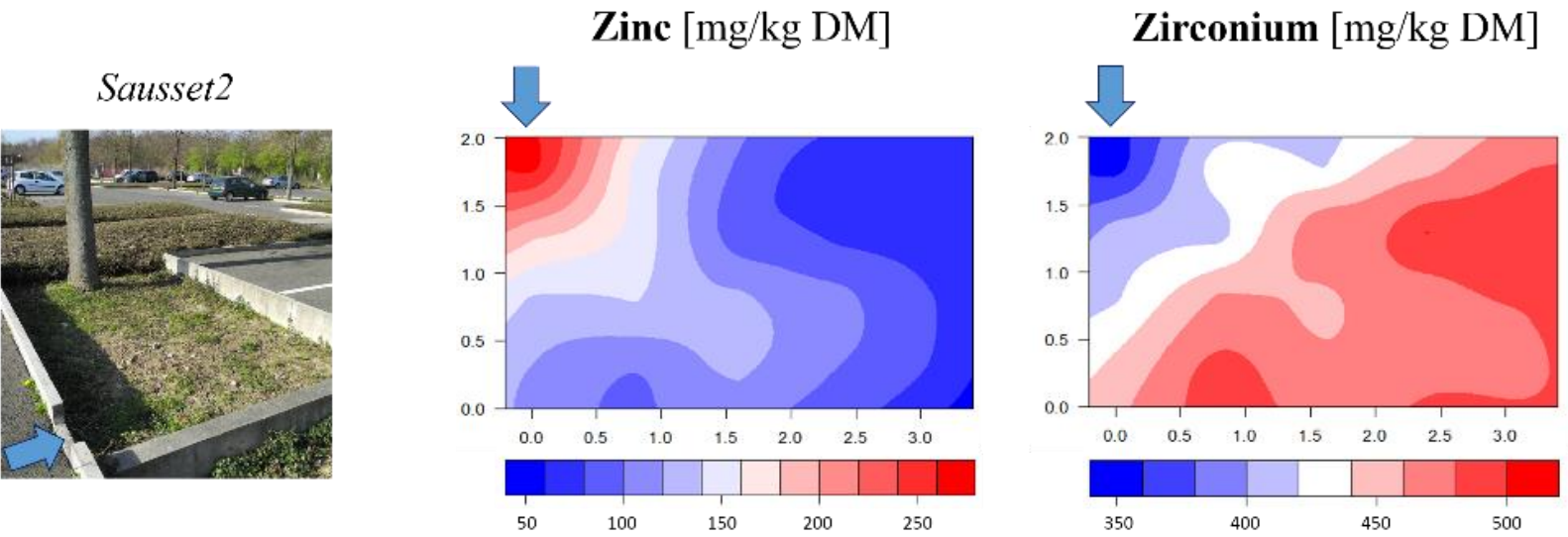

Vitry
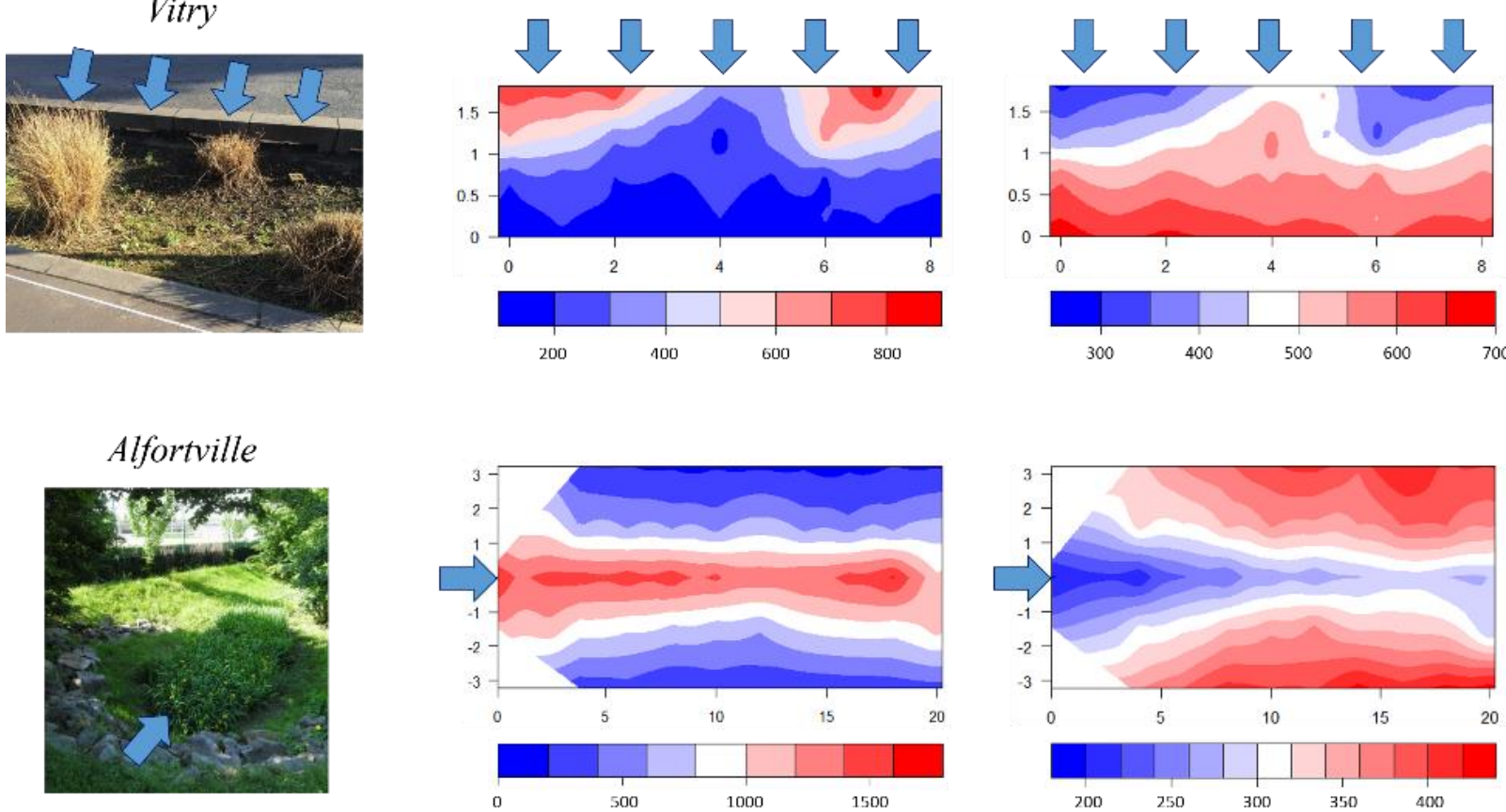

Figure 3 - Spatial distribution of zinc and zirconium $[\mathrm{mg} / \mathrm{kg} \mathrm{DM}]$ in the surface soil of the study sites Sausset2, Vitry, and Alfortville (plan view). The $\mathrm{x}$ - and $\mathrm{y}$-coordinates are given in meters. The arrows indicate the water inflow.

Zinc $[\mathrm{mg} / \mathrm{kg}$ DM]

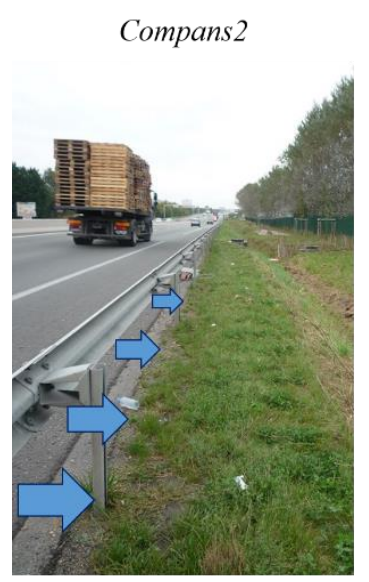

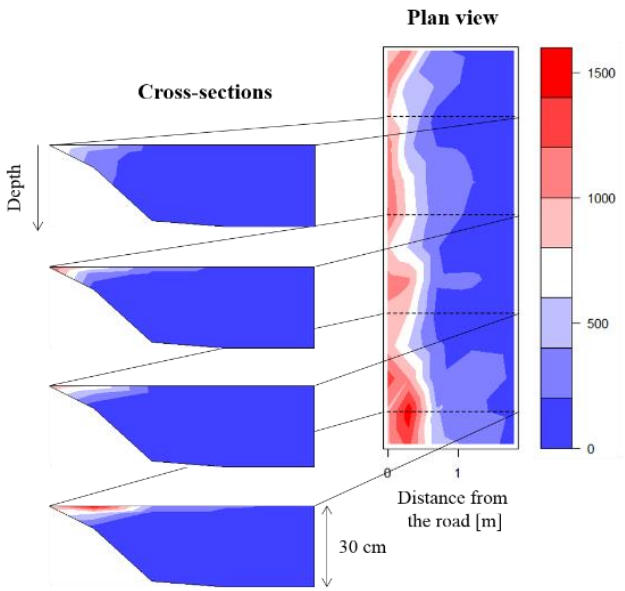

Zirconium [mg/kg DM]

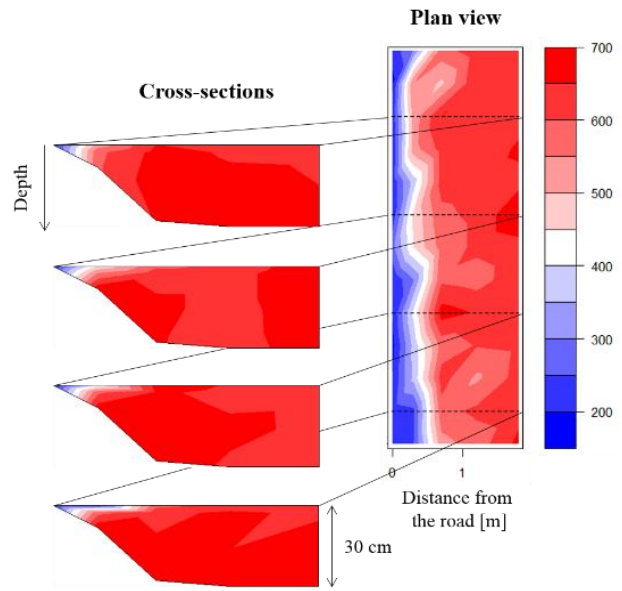

Figure 4 - Spatial distribution of zinc and zirconium $[\mathrm{mg} / \mathrm{kg} \mathrm{DM}]$ in the surface soil and along four crosssections of the filter strip Compans2. 


\section{2 $\mathrm{Zr}$ levels in soil and raw sediment}

$\mathrm{Zr}$ content was fairly consistent between sites in samples of road-deposited sediment, ranging from 175 to $214 \mathrm{mg} / \mathrm{kg}$ DM (Table 2), in accordance with the previous observations of Apeagyei et al. (2011). Conversely, the contents found in the reference zone were site-specific, but always greater than in sediment. These values were coherent with the reported levels in soils from the Paris area (Salminen, 2005) albeit slightly higher on average. The Compans 3 swale was the only site where the difference between soil and sediment was $<50 \mathrm{mg} / \mathrm{kg}$ DM. In all sites except Greffiere, Chanteraines, and Compans3, the values measured in raw sediment and in non-contaminated soil constituted the two bounds of $\mathrm{Zr}$ contents at the surface of the infiltration facilities.

Table 2 - Zr contents in the collected sediment samples and in the reference zone of the study sites. Comparison with literature data for road dust and worldwide soils.

\begin{tabular}{lll}
\hline Site & $\mathbf{Z r}_{\text {sediment }}[\mathbf{m g} / \mathbf{k g ~ D M}]$ & $\mathbf{Z r}_{\text {reference }}$ [mg/kg DM] \\
\hline Dourdan & 175 & 420 \\
Greffiere & 214 & 280 \\
Alfortville & Not sampled & 418 \\
Sausset1 & Not sampled & 626 \\
Sausset2 & Not sampled & 501 \\
Chanteraines & 178 & 340 \\
Vitry & 209 & 650 \\
Vaucresson & 195 & 720 \\
Compans1 & 201 & 370 \\
Compans2 & 190 & 695 \\
Compans3 & 203 & 241 \\
\hline Urban road dust (Apeagyei et al., 2011) & $180 \pm 52$ (N = 41) & \\
Soils from the Paris area (Salminen, 2005) & & $406 \pm 137$ (N = 21) \\
Worldwide soils (Kabata-Pendias, 2011) & & $200-850$ \\
Worldwide soils (Pais and Jones, 1983) & & $60-2000$ \\
American soils (Coughtrey and Thorne, 1983) & & $70-890$ \\
\hline Sediment deposits could not be found in the immediate vicinity of the sites Alfortille and Sausset.
\end{tabular}

${ }^{\$}$ Sediment deposits could not be found in the immediate vicinity of the sites Alfortville and Sausset.

\subsection{Vertical distribution of $\mathrm{Zr}$}

In Compans 1 and 2, the cross-sections showed that $\mathrm{Zr}$ deficit was globally restricted to the upper 5 centimeters alongside the road; the rest of the filter strips displayed almost uniform contents (Figure 4). In the most contaminated zone of the other facilities, $\mathrm{Zr}$ content generally tended to increase with depth which, as for the cartographies, was the opposite trend compared to metals (Tedoldi et al., 2017b). In comparison with the reference profiles, which showed little variability, $\mathrm{Zr}$ deficit in the contaminated zone 
was visible up to a depth of 5 to $15 \mathrm{~cm}$ (Figure 5). In Alfortville, the transition between the surface soil and the above-mentioned clay horizon caused a sharp decrease in the measured values (Figure 5a).
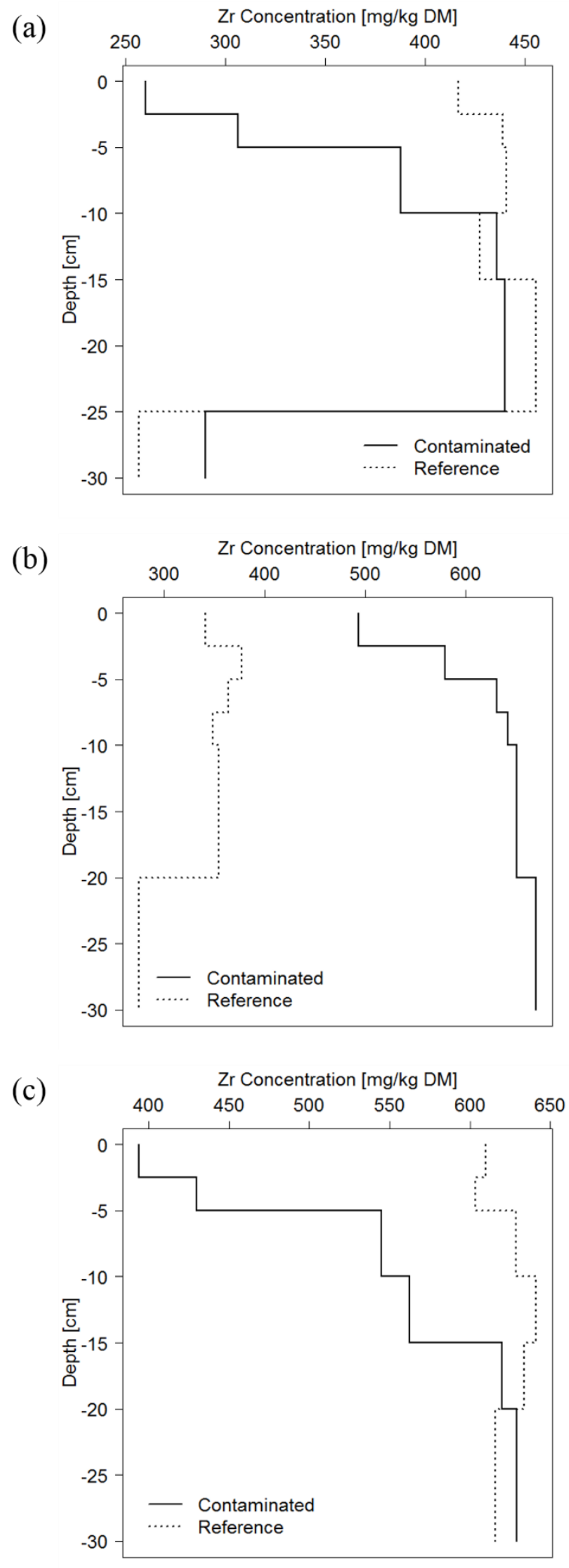

Figure 5 - Vertical distribution of the $\mathrm{Zr}$ contents [mg/kg DM], in the most and the least contaminated zones of the study sites (a) Alfortville, (b) Chanteraines, and (c) Vitry. 
The observations were somewhat different in Chanteraines, where the contents measured in the contaminated zone increased with increasing depth, but were significantly higher than in the reference zone (Figure 5b). In Greffiere and Compans3, similar to what was found at the surface, $\mathrm{Zr}$ contents did not show any particular trend with depth and fell in a relatively narrow range of values (225-330 and 185$310 \mathrm{mg} / \mathrm{kg}$ DM, respectively).

\section{DISCUSSION}

\subsection{Quantification of the sediment fraction}

Both horizontally and vertically, a depletion of zirconium (with respect to the site-specific reference values) has been noticed near the inflow zone. Yet, because of its very low mobility in soil, $\mathrm{Zr}$ is not likely to have been lixiviated from the upper horizons by the infiltrating water. Hence, the present observations may be explained by the fact that the collected samples were actually a mixture of original soil and other material(s) with different elemental compositions and lower contents of zirconium, resulting in a "dilution" effect in the solid phase. These materials may consist of (i) accumulated sediment and/or (ii) humus, both of which are likely to be preferentially found near the inflow zone of the devices - vegetation growth was observed to be fostered in the most frequently flooded area, resulting in higher volatile contents (El-Mufleh et al., 2014; Tedoldi et al., 2017a). The typically increasing Zr profiles (i.e. decreasing “dilution”) with increasing depth over $5-15 \mathrm{~cm}$ are also consistent with this interpretation, because of (i) filtration processes in the soil matrix, and (ii) formation of soil organic matter from the surface litter.

So as to isolate the contribution of sediment accumulation versus organic matter production, $\mathrm{Zr}$ contents in every collected sample were expressed per kilogram of mineral matter (MM) rather than per kilogram of dry matter, knowing the volatile matter content of each sample. This approach relies on the assumption that $\mathrm{Zr}$ content in the organic fraction is negligible with respect to the mineral fraction, which seems accurate given its lithogenic sources and low availability to plants (Shahid et al., 2013); for instance, Kabata-Pendias (2011) reported very low $\mathrm{Zr}$ contents in histosols, which essentially consist of organic materials $(\sim 30 \mathrm{mg} / \mathrm{kg} \mathrm{DM})$. Therefore, the "corrected" contents $C^{*}$, which are assumed to reflect only the mixture of soil and sediment, may be written as:

$$
C^{*}=f C_{\text {sediment }}^{*}+(1-f) C_{\text {reference }}^{*}
$$

where $C_{\text {sediment }}^{*}$ and $C_{\text {reference }}^{*}$ are the $\mathrm{Zr}$ contents in the mineral fraction of raw sediment, and reference soil, respectively [mg/kg MM], and $f$ is the mass fraction of sediment in the sample [-]. In case raw sediment could not be sampled in the immediate vicinity of the infiltration systems (Alfortville, Sausset), the retained value for $C_{\text {sediment }}^{*}$ was the average of the measurements in sediment samples across all sites (210 mg/kg MM). Eventually, in all facilities except Greffiere, Chanteraines, and Compans3, the spatial distribution of $C^{*}(x, y)$ in the surface soil enabled the determination of the coefficient $f(x, y)$; in other words, the importance of sediment accumulation could be spatialized (Figure 6). Logically, $f$ was higher in 
the inflow zone of each investigated system (up to $80 \%$ in Vitry and Vaucresson, and almost 100\% in Compans 1 and 2), demonstrating that particle settling predominantly occurs in a relatively narrow area.

(a)

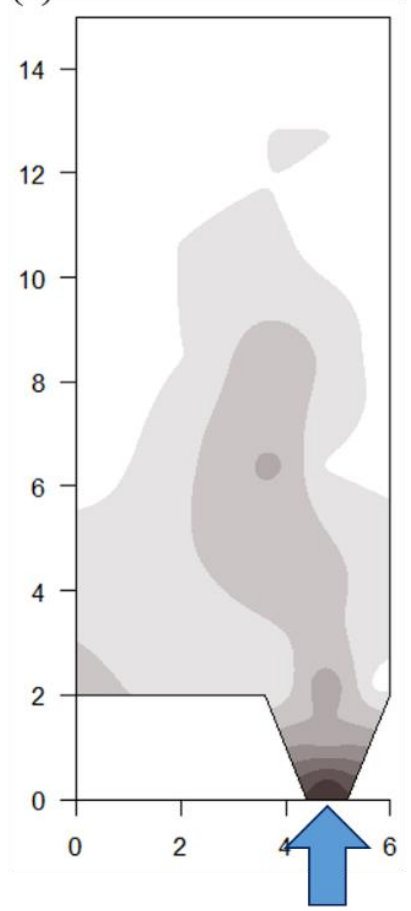

(b)
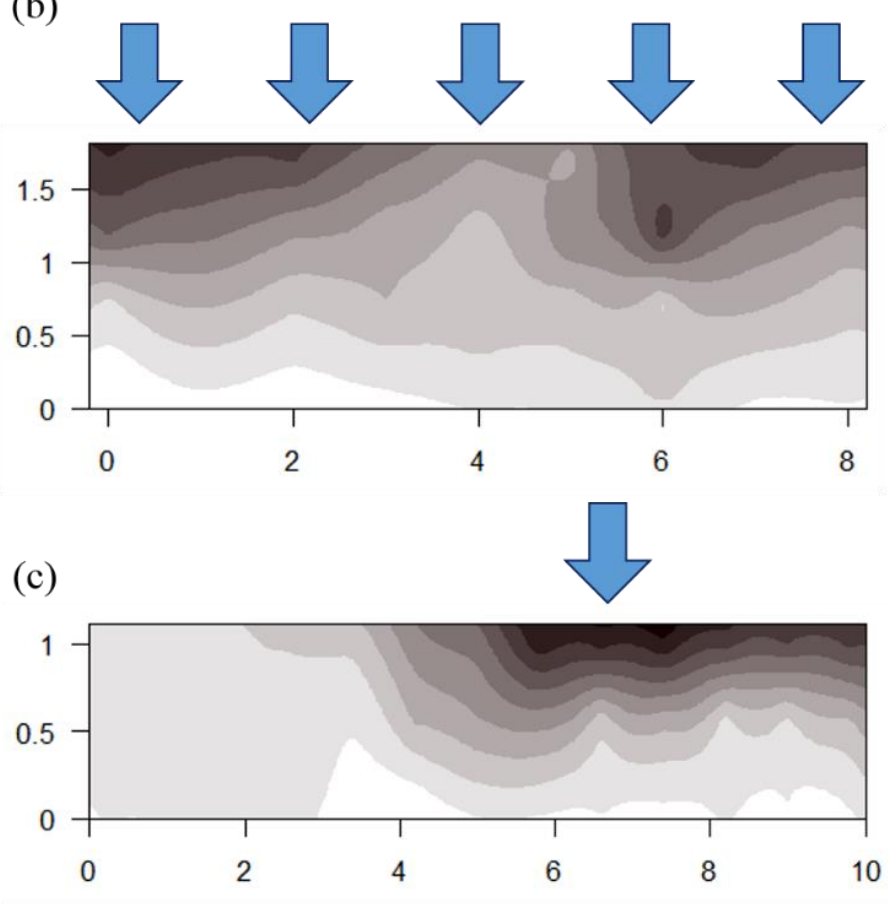

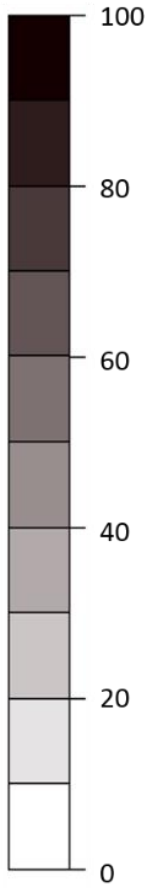

Figure 6-Spatial distribution of the sediment fraction $f[\%]$ at the surface of the study sites (a) Sausset1, (b) Vitry, and (c) Vaucresson (plan view). The arrows indicate the water inflow.

As regards the "exception sites" with dissimilar behaviors, it should be underlined that the Greffiere facility was implemented in a residential area with a priori low suspended solid loads, while the heterogeneity observed in the Chanteraines and Compans 3 swales may be attributed to an uneven mixture of the soil material during their construction. In the former case, this would also explain the dissimilarity in $\mathrm{Zr}$ profiles between the contaminated and the reference zones (Figure $5 \mathrm{~b}$ ), which was also visible with the distribution of other metals or pedological parameters such as cation exchange capacity or carbonates (Tedoldi et al., 2017b). In the latter case, not only was the differential between the sediment and soil relatively small, but also the operating time of the system (1 year) was probably insufficient to observe a significant sediment buildup in the swale.

By applying equation (1) to $\mathrm{Zr}$ profiles, the fraction $f$ could also be determined and plotted as a function of depth. $C_{\text {reference }}^{*}$ was taken as the mean value of the corrected contents over 0-30 cm depth in the reference zone, excluding the deepest sample in Alfortville, as it corresponded to a different horizon of soil. However, the retained value for $C_{\text {reference }}^{*}$ in Chanteraines was the content in the deepest sample from the most contaminated zone $(700 \mathrm{mg} / \mathrm{kg} \mathrm{MM})$ because of the differences in elemental composition between the two parts of the swale. Although the results from Compans 1 and 2 suggested a "cake filtration" effect near the pavement (Figure 4), the profiles obtained in the other sites (except Greffiere and Compans3) depicted the accumulation of suspended solids within the soil matrix and thus proved the occurrence of bed filtration 
over 5 to $15 \mathrm{~cm}$, in addition to sediment accumulation at the surface (Figure 7). The calculations showed that there were almost $20 \%$ of sediments in the $5-10 \mathrm{~cm}$ segment of Alfortville and Vitry, indicating a state of advanced clogging, contrary to the other sites. The penetration of such quantities of sediments at this depth is plausible, considering the age of the devices, the significant suspended solid production from their catchments (industrial areas with high truck traffic), and the renewal of the soil porosity near the surface due to vegetation roots and biological activity, as described by Paus et al. (2013) and Cannavo et al. (2018).

\subsection{Calibration of a filtration model}

Theoretical background. A series of models with contrasting complexity are available to describe the attachment and transfer of suspended solids within a porous material, using either a microscopic or a macroscopic approach (Logan, 2001; Li and Davis, 2008b). Among the second category, the simplest one is usually referred to as Iwasaki's model (Iwasaki, 1937), which consists of a set of two equations:

$$
\begin{gathered}
q \frac{\partial C_{p}}{\partial z}+\frac{\partial \sigma_{p}}{\partial t}=0 \\
\frac{\partial C_{p}}{\partial z}=-\lambda C_{p}
\end{gathered}
$$

where $C_{p}$ is the mass concentration of particles in the percolating water [M.L-3], $q$ is the Darcy velocity $\left[{\mathrm{L} . \mathrm{T}^{-1}}^{-1}, \sigma_{p}\right.$ is the mass of deposited solids per unit bed volume [M.L. $\left.{ }^{-3}\right], z$ is the vertical coordinate [L] (increasing downwards), and $\lambda$ is called the filter coefficient $\left[\mathrm{L}^{-1}\right]$. Equation (2) is a simplified form of the continuity equation, which expresses the mass balance between the solids removed from suspension and those deposited in the pores of the media. In equation (3), a high value of $\lambda$ indicates a good efficiency of the media for particle retention, resulting in an important accumulation near the surface. Some studies introduced an empirical relationship $\lambda=f\left(\sigma_{p}\right)$ to represent the effects of progressive soil clogging (Logan, 2001). In case $\lambda$ is assumed constant, this parameter is often estimated experimentally from the ratio between influent and effluent concentrations, considering either soil columns, or in-situ bioretention systems (Li and Davis, 2008a,b). Yet, it is onerous and not always possible to collect the effluent water, especially in infiltration devices which are not equipped with an underdrain. Although several authors proposed analytical expressions for the parameter $\lambda$, e.g. as a function of the bed porosity and size of the "collectors", they still introduced empirical parameters such as the "attachment efficiency" or the "collision efficiency" of the particles (Yao et al., 1971), which are not immediately available.

As the present approach directly provides the vertical distribution of filtered solids in the soil, it may be valuably used to calibrate such models. The mass content of retained particles $\sigma_{m}$ (i.e. expressed per unit bed mass) is linked to the variable $\sigma_{p}$ via the relationship $\sigma_{p}=\rho \sigma_{m}$, where $\rho$ is the bulk density of the porous media $\left[\mathrm{M} . \mathrm{L}^{-3}\right]$ - so combining equations 2 and 3 yields:

$$
\frac{\partial \sigma_{m}}{\partial t}=\frac{\lambda}{\rho} q C_{p}
$$

Time integration of equation (4) finally leads to: 


$$
\sigma_{m}(z, t)=\sigma_{0}(z)+\frac{\lambda}{\rho} \int_{0}^{t} q(z, \tau) C_{p}(z, \tau) d \tau
$$

If the soil is assumed to be initially clean $\left(\sigma_{0}=0\right)$, and $q$ is assumed to be uniform on average over the considered soil depth $(30 \mathrm{~cm})$ - which seems acceptable for the most contaminated zone, as it corresponds to the most frequently flooded area where the infiltration fluxes are concentrated - then the variable $\sigma_{m}$ theoretically follows the same spatial variations as $C_{p}$, i.e. the exponential distribution imposed by equation (3).

Application to the data. A linear regression was carried out on the log-transformed fraction $f$ as a function of $z$, assigning to each vertical segment its average depth. The satisfactory adjustment provided by the linear model in Alfortville, Sausset1, Sausset2, Chanteraines, and Vitry $\left(\mathrm{R}^{2}>0.85\right)$ confirmed the validity of these theoretical developments. The filter coefficient $\lambda$ was estimated as the slope of the regression and ranged from $0.12 \mathrm{~cm}^{-1}$ (in Vitry) to $0.20 \mathrm{~cm}^{-1}$ (in Alfortville). These values are consistent with the data reported by Leclerc (1998), which varied between 0.08 and $0.50 \mathrm{~cm}^{-1}$. They are slightly lower than the experimental measurements carried out by Li and Davis (2008b) in soil columns, which fell between 0.34 and $0.55 \mathrm{~cm}^{-1}$, but higher than the same authors' in-situ estimations on a bioretention cell (0.01-0.06 $\left.\mathrm{cm}^{-1}\right)(\mathrm{Li}$ and Davis, 2008a). These differences can be explained by the fact that (i) for column experiments, the soil material is generally homogenized and uniformly packed, so the filtration performance may be expected to be higher than for a real system, (ii) the particle size and pore size distributions are likely to be different between the presently assessed devices and the above-mentioned bioretention cell (made of 50\% sand, 30\% topsoil, and $20 \%$ mulch), and (iii) when studying a real system, soil particles may be lixiviated during water infiltration, thus leading to an underestimation of the filter coefficient.

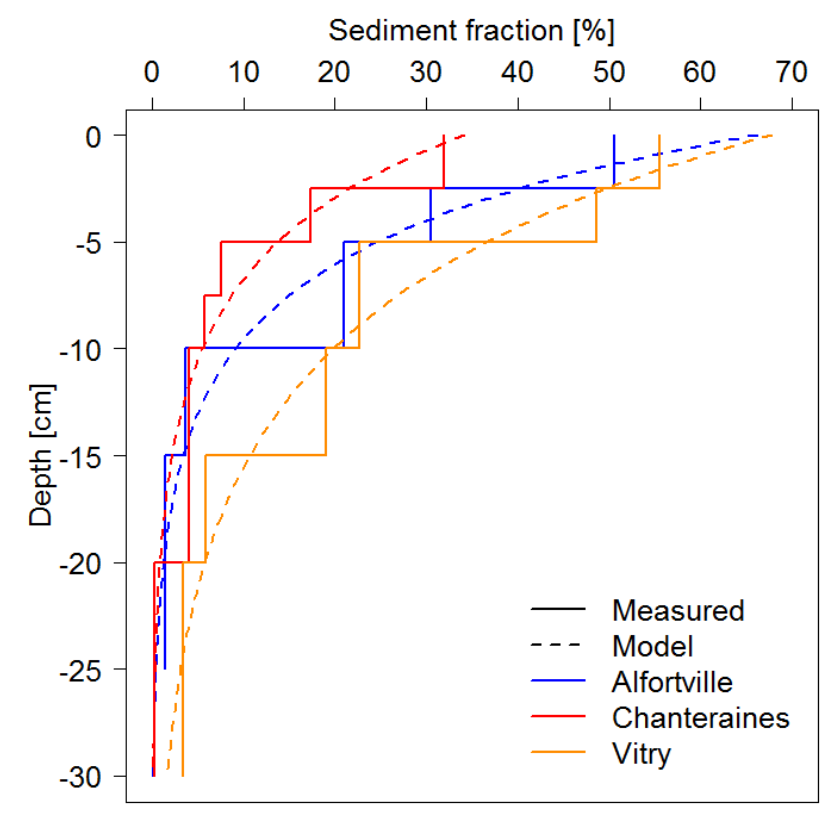

Figure 7 - Measured (solid lines) and calibrated (dotes lines) sediment fraction $f[\%]$ as a function of depth, in the study sites Alfortville, Chanteraines, and Vitry. 


\subsection{Uncertainties, applicability and limits of the method}

The objective of this section is to assess the robustness of the results with respect to the uncertainties on the $\mathrm{Zr}$ contents, which can be classified into four components. (i) Analytical uncertainties are related to the repeatability of the XRF measurements, which was characterized by an average coefficient of variation of $3 \%$ (calculated from the 5 to 6 analyses carried out on different subsamples) and modelled with a normal distribution centered about the mean value for each sample. (ii) $\mathrm{Zr}$ contents in the reference zone were never exactly uniform, as a result of which the retained values for $C_{\text {reference }}^{*}$ may be somewhat biased. The "local", site-specific variability of reference contents was represented with a normal distribution for each device. (iii) In spite of a relative inter-site stability of the $\mathrm{Zr}$ content in raw sediment, some uncertainty is associated with the estimation of $C_{\text {sediment }}^{*}$ when sediment samples could not be collected on the nearby pavement. Between sites, values ranged from 195 to $238 \mathrm{mg} / \mathrm{kg} \mathrm{MM}$, and this interval extended to $187-247 \mathrm{mg} / \mathrm{kg} \mathrm{MM}$ when accounting for the analytical uncertainties. Accordingly, the uncertainty about $C_{\text {sediment }}^{*}$ in Alfortville and Sausset was represented with a uniform distribution. (iv) Finally, it should be mentioned that the particles which are most likely to settle on the road are the coarser ones, and thus may be non-representative of the entire distribution of suspended solids in runoff (e.g. with lower organic matter contents), but this point was not accounted for in the subsequent calculations.

These uncertainties imply the existence of a minimal degree of dilution below which sediment accumulation cannot be considered as significant (i.e. the hypothesis that $f=0$ cannot be rejected). Evidently, the greater the difference between $C_{\text {reference }}^{*}$ and $C_{\text {sediment }}^{*}$, the lower is the "limit of quantification" of the sediment fraction, which was found to lie between 7 and 11\% (w/w) for Dourdan, Alfortville, Sausset1 and 2, Chanteraines, Vitry, Vaucresson, and Compans2. Conversely, this value was higher in Compans1 ( 25\%) and Greffiere ( $\sim 75 \%$ ), while it was almost $100 \%$ in Compans 3 due to notably low $\mathrm{Zr}$ contents in the filter media.

Finally, a stochastic approach was carried out in order to assess the impact of these uncertainties on the calculated filter coefficient. The estimation procedure was repeated 10000 times for each site, with $C_{\text {sediment }}^{*}$ and $C_{\text {reference }}^{*}$ randomly sampled from their respective distributions, leading to statistical data for the parameter $\lambda$. In the three examples displayed in Figure 7, the associated $95 \%$ confidence intervals were $0.11-0.30 \mathrm{~cm}^{-1}$ for Alfortville, $0.08-0.34 \mathrm{~cm}^{-1}$ for Chanteraines, and $0.08-0.20 \mathrm{~cm}^{-1}$ for Vitry. Therefore, although the proposed method appears to be somewhat sensitive to the estimated zirconium content in both raw sediment and non-contaminated soil, the resulting uncertainty on the parameter $\lambda$ is quite comparable to the other experimental methods, and one of its major improvements lies in the fact that the procedure does not require sampling soil water.

The study sites Greffiere and Compans3, along with Chanteraines for the cartography stage, provided three examples where the proposed methodology is not applicable:

i. the geochemical background of $\mathrm{Zr}$ is close to the content in raw sediment; 
ii. sediment accumulation is not sufficient to discriminate between $\mathrm{Zr}$ deficit and the natural variations of this element - either due to a short operating time or to low suspended solid loads from the watershed;

iii. the mixing of the soil material before backfilling the infiltration devices is uneven.

Regarding the first point, the variability of $\mathrm{Zr}$ levels in worldwide soils (as reported in Table 2) suggests that this method may be successfully implemented in many contexts beyond the Paris region, excluding the zones with $\mathrm{Zr}$ contents close to the "critical" value of $200 \mathrm{mg} / \mathrm{kg} \mathrm{DM}$ - or perhaps biofiltration systems composed of an engineered filter media, the composition of which may be different from natural soils. In such cases, the present approach is certainly transposable with another tracer among the usual geochemical invariants (e.g. titanium or aluminum), which should be further investigated and may enable the validation of the results obtained with zirconium.

\section{CONCLUSIONS AND PERSPECTIVES}

The present work validated the use of zirconium as a tracer of sediment accumulation in soil-based Sustainable Urban Drainage Systems. Zr and metal levels were analyzed in road-deposited sediment as well as more than 500 surface soil samples and 175 samples along vertical profiles from 11 study sites. $\mathrm{Zr}$ content in "raw" sediment was found to be significantly lower than in non-contaminated soil, with a noteworthy inter-site stability. In most devices, $\mathrm{Zr}$ showed "mirror" distributions with respect to metals, i.e. a deficit of $\mathrm{Zr}$ could be noticed horizontally and vertically in the most contaminated zone. Since $\mathrm{Zr}$ is unlikely to be leached or taken up by plants because of its physicochemical properties, this observation was interpreted as the result of a "dilution" in the solid phase due to sediment accumulation. The "dilution ratio" enabled the calculation of the sediment fraction, the spatial variability of which provided evidence for the joint occurrence of particle settling over a limited part of the surface and bed filtration within the soil matrix.

Several sources of uncertainty, including the repeatability of the analyses and the natural variability of $\mathrm{Zr}$ in soil, resulted in a site-specific "limit of quantification" for the sediment fraction, which was generally found to be around $10 \%(\mathrm{w} / \mathrm{w})$, except when the geochemical background was close to the $\mathrm{Zr}$ level in sediment. Hence the proposed approach appeared to be reasonably precise and appropriate for many geological contexts beyond the present experimental area. These findings were used to calibrate a simple, onedimensional filtration model. In most study sites, the measured profiles were consistent with the exponential distribution derived from Iwasaki's equation, and the filter coefficient could be calculated with a controlled confidence interval. The accuracy of the measurement was comparable with other methods available in the literature, and the approach presented the considerable advantage that it did not require sampling soil water. Another perspective of this work may be to further investigate the occurrence of soil clogging in infiltration 
systems, so as to better understand the antagonistic effects of particle accumulation versus biological renewal of the soil porosity.

\section{ACKNOWLEDGEMENTS}

This research was carried out under the OPUR and ROULEPUR research programs. The authors gratefully acknowledge OPUR partners (AESN, SIAAP, CD92, CD93, CD94, Ville de Paris), French Agency for Biodiversity (AFB) and Seine-Normandie Water Agency for their financial support, as well as the French territorial collectivities which allowed the authors to perform soil samplings in their devices.

\section{REFERENCES}

Apeagyei, E., Bank, M. S., Spengler, J. D. Distribution of heavy metals in road dust along an urban-rural gradient in Massachusetts. Atmospheric Environment, 2011, 45(13), 2310-2323.

Cannavo, P., Coulon, A., Charpentier, S., Béchet, B., Vidal-Beaudet, L. Water balance prediction in stormwater infiltration basins using 2-D modeling: An application to evaluate the clogging process. International Journal of Sediment Research, 2018, in press.

Coughtrey, P.-J., Thorne, M.-C. Radionuclide distribution and transport in terrestrial and aquatic ecosystems : a critical review of data. Volume one. A. A. Balkema, Rotterdam, 1983.

Clark, S. E., Pitt, R. Targeting treatment technologies to address specific stormwater pollutants and numeric discharge limits. Water Research, 2012, 46, 6715-6730.

Dierkes, C., Lucke, T., Helmreich, B. General technical approvals for decentralised Sustainable Urban Drainage Systems (SUDS) - The current situation in Germany. Sustainability, 2015, 7(3), 3031-3051.

Egli, M., Fitze, P. Formulation of pedologic mass balance based on immobile elements: a revision. Soil Science, 2000, 165(5), 437-443.

El-Mufleh, A., Béchet, B., Ruban, V., Legret, M., Clozel, B., Barraud, S., Gonzalez-Merchan, C., Bedell, J.-P., Delolme, C. Review on physical and chemical characterizations of contaminated sediments from urban stormwater infiltration basins within the framework of the French observatory for urban hydrology (SOERE URBIS). Environmental Science and Pollution Research, 2014, 21(8), 5329-5346.

Erickson, A. J., Weiss, P. T., Gulliver, J. S. Optimizing stormwater treatment practices: a handbook of assessment and maintenance. Springer, New York, 2013.

Flanagan, K., Tedoldi, D., Branchu, P., Gromaire, M.-C. Caractérisation du fonctionnement d'un ouvrage de gestion à la source du ruissellement de voirie : approche par modélisation hydrologique et par cartographie de la contamination du sol. La Houille blanche, 2017, 3, 5-13.

Fletcher, T. D., Andrieu, H., Hamel, P. Understanding, management and modelling of urban hydrology and its consequences for receiving waters; a state of the art review. Advances in Water Resources, 2013, $51,261-279$.

Fletcher, T. D., Shuster, W., Hunt, W. F., Ashley, R., Butler, D., Arthur, S., Trowsdale, S., Barraud, S., Semadeni-Davies, A., Bertrand-Krajewski, J.-L., Mikkelsen, P. S., Rivard, G., Uhl, M., Dagenais, D., 
Viklander, M. SUDS, LID, BMPs, WSUD and more - The evolution and application of terminology surrounding urban drainage. Urban Water Journal, 2015, 12(7), 525-542.

Göbel, P., Dierkes, C., Coldewey, W. G. Storm water runoff concentration matrix for urban areas. Journal of Contaminant Hydrology, 2007, 91(1-2), 26-42.

Hatt, B. E., Fletcher, T. D., Walsh, C. J., Taylor, S. L. The influence of urban density and drainage infrastructure on the concentrations and loads of pollutants in small streams. Environmental Management, 2004, 34(1), 112-124.

Huber, M., Welker, A., Helmreich, B. Critical review of heavy metal pollution of traffic area runoff: Occurrence, influencing factors, and partitioning. Science of the Total Environment, 2016, 541, 895-919.

ISO 11464. Soil quality - Pretreatment of samples for physico-chemical analysis. International Organization for Standardization, Geneva, 2006.

Iwasaki, T. Some notes on sand filtration. American Water Works Association, 1937, 29, 1591-1602.

Kabata-Pendias, A. Trace Elements in Soils and Plants, Fourth edition. CRC Press, Boca Raton, 2011.

Kluge, B., Wessolek, G. Heavy metal pattern and solute concentration in soils along the oldest highway of the world - the AVUS Autobahn. Environmental Monitoring and Assessment, 2012, 184(11), 6469-6481.

Leclerc, D. Filtration en profondeur - Aspects théoriques. Techniques de l'ingénieur, 1998, 1-8.

Li, H., Davis, A. P. Heavy metal capture and accumulation in bioretention media. Environmental Science and Technology, 2008a, 42(14), 5247-5253.

Li, H., Davis, A. P. Urban particle capture in bioretention media. II: Theory and model development. Journal of Environmental Engineering, 2008b, 134(6), 419-432.

Logan, J. D. Transport Modeling in Hydrogeochemical Systems. Springer, New York, 2001.

McGrane, S. J. Impacts of urbanisation on hydrological and water quality dynamics, and urban water management: a review. Hydrological Sciences Journal, 2016, 61(13), 2295-2311.

Miller, J. D.; Kim, H.; Kjeldsen, T. R.; Packman, J.; Grebby, S. Assessing the impact of urbanization on storm runoff in a peri-urban catchment using historical change in impervious cover. Journal of Hydrology, 2014, 515, 59-70.

Mohiuddin, K. M., Zakir, H. M., Otomo, K., Sharmin, S., Shikazono, N. Geochemical distribution of trace metal pollutants in water and sediments of downstream of an urban river. International Journal of Environmental Science and Technology, 2010, 7(1), 17-28.

Napier, F., Jefferies, C., Heal, K. V., Fogg, P., d'Arcy, B. J., Clarke, R. Evidence of traffic-related pollutant control in soil-based Sustainable Urban Drainage Systems (SUDS). Water Science and Technology, 2009, 60(1), 221-230.

Pais, I., Jones, J. B. The Handbook of Trace Elements, CRC Press, Boca Raton, 1983.

Paus, K. H., Morgan, J., Gulliver, J. S., Leiknes, T., Hozalski, R. M. Assessment of the hydraulic and toxic metal removal capacies of bioretention cells after 2 to 8 years of service. Water, Air and Soil Pollution, 2013, 225(1), 1803. 
Salminen, R. (Chief ed.). Geochemical Atlas of Europe. Part 1 - Background Information, Methodology, and Maps. Geological Survey of Finland, Espoo, 2005.

Schulz, R. K. Soil chemistry of radionuclides. Health Physics, 1965, 11(12), 1317-1324.

Shahid, M., Ferrand, E., Schreck, E., Dumat, C. Behavior and impact of zirconium in the Soil-Plant System: Plant uptake and phytotoxicity. Reviews of Environmental Contamination and Toxicology, 2013, 221, 107127.

Sposito, G. The chemistry of soils, second edition. Oxford University Press, Oxford, 2008.

Stockmann, U., Cattle, S. R., Minasny, B., McBratney, A. B. Utilizing portable X-ray fluorescence spectrometry for in-field investigation of pedogenesis. Catena, 2016, 220-231, 139.

Tedoldi, D., Chebbo, G., Pierlot, D., Kovacs, Y., Gromaire, M.-C. Impact of runoff infiltration on contaminant accumulation and transport in the soil/filter media of Sustainable Urban Drainage Systems: A literature review. Science of the Total Environment, 2016, 569-570, 904-926.

Tedoldi, D., Chebbo, G., Pierlot, D., Branchu, P., Kovacs, Y., Gromaire, M.-C. Spatial distribution of heavy metals in the surface soil of source-control stormwater infiltration devices - Inter-site comparison. Science of the Total Environment, 2017a, 579, 881-892.

Tedoldi, D., Chebbo, G., Pierlot, D., Kovacs, Y., Gromaire, M.-C. Assessment of metal and PAH profiles in SUDS soil based on an improved experimental procedure. Journal of Environmental Management, 2017b, 202, 151-166.

Yao, K.-M., Habibian, M. T., O'Melia, C. R. Water and waste water filtration: Concepts and applications. Environmental Science and Technology, 1971, 5(11), 1105-1112. 